\title{
Prosódia de enunciados declarativos e interrogativos totais nas variedades de Salvador, Fortaleza e Rio de Janeiro
}

\section{Prosody of declarative and interrogative modalities in Salvador, Fortaleza and Rio de Janeiro varieties}

Leticia Rebollo Couto

Universidade Federal do Rio de Janeiro, Rio de Janeiro, Rio de Janeiro / Brasil rebollocouto@yahoo.fr

Carolina Gomes da Silva

Universidade Federal da Paraíba, João Pessoa, Paraíba / Brasil

Universidade Federal do Rio de Janeiro, Rio de Janeiro, Rio de Janeiro / Brasil carolinagsufpb@gmail.com

Luma da Silva Miranda

Universidade Federal do Rio de Janeiro, Rio de Janeiro, Rio de Janeiro / Brasil CAPES

lumah.miranda@gmail.com

Resumo: Este trabalho tem como objetivo descrever diferenças entre variedades dialetais do português falado em Salvador, Fortaleza e Rio de Janeiro, Brasil, tanto nas sentenças declarativas quanto nas interrogativas. A análise de parâmetros prosódicos (frequência fundamental, duração, intensidade) é feita no núcleo final de sentenças oxítonas, paroxítonas e proparoxítonas. Há diferenças prosódicas sistemáticas entre as duas modalidades (declarativa e interrogativa): um tom alto ou subida de F0 no núcleo das interrogativas e, ao contrário, um tom baixo ou descida de F0 no núcleo das declarativas. Variações dialetais também são observadas. Os acentos tonais nucleares $\mathrm{H}+\mathrm{L} * \mathrm{~L} \%$ para as declarativas e $\mathrm{L}+\mathrm{H} * \mathrm{~L} \%$ para as interrogativas, propostos por Moraes (2008), são observados nos falantes do Rio de Janeiro - sendo este último truncado ou comprimido 
em sentenças oxítonas, devido à falta do material postônico. Entretanto, nas variedades de Salvador e Fortaleza, as interrogativas também podem ser realizadas com um padrão $\mathrm{L}+\mathrm{H}^{*} \mathrm{H} \%$. Maior elisão de sílabas é observada nos falantes de Fortaleza.

Palavras-chave: prosódia; entoação; sentenças declarativas; sentenças interrogativas totais; variação dialetal.

Abstract: This work aims at describing differences between the dialectal varieties of Portuguese spoken at Salvador, Fortaleza and Rio de Janeiro, Brazil, in both the declarative and interrogative modalities. Analyses of prosodic parameters (fundamental frequency, duration, intensity) are made on the final nucleus of oxytonic, paroxytonic and proparoxytonic sentences. There are systematic prosodic changes between modalities - with a higher / rising F0 in interrogative nucleus where it is lower / decreasing for declaratives. The interrogative nucleus are also longer and stronger than the declaratives. Dialectal variations are also observed. The accentual patterns $\mathrm{H}+\mathrm{L} * \mathrm{~L} \%$ for declaratives and $\mathrm{L}+\mathrm{H}^{*} \mathrm{~L} \%$ for interrogatives proposed by Moraes (2008) are observed in Rio de Janeiro speakers - the latter being truncated or compressed in oxytonic sentences due to lack of post-tonic material. Meanwhile, in the Salvador and Fortaleza varieties, interrogatives may also be performed with a $\mathrm{L}$ $+\mathrm{H}^{*} \mathrm{H} \%$ pattern. More syllable elisions are also observed in Fortaleza speakers.

Keywords: prosody; intonation; declarative sentences; yes/no questions; dialectal variation.

Recebido em: 5 de janeiro de 2017.

Aprovado em: 14 de março de 2017.

\section{Introdução}

A proposta deste trabalho é descrever e comparar elementos prosódicos de enunciados interrogativos totais e declarativos do corpus experimental AMPER (Atlas Multimédia Prosódico do Espaço 
Românico) ${ }^{1}$ para o português do Brasil: projeto AMPER Por (Brasil). Os dados que analisamos neste artigo são referentes a três pontos de coleta, duas capitais na região nordeste do Brasil - Salvador e Fortaleza - e uma na região sudeste - Rio de Janeiro. Analisamos a variação do padrão entonacional e a implementação dos parâmetros acústicos frequência fundamental (F0), duração e intensidade no núcleo e no pré-núcleo dos seguintes enunciados: "O Renato gosta do Renato", "O pássaro gosta do pássaro", "O bisavô gosta do bisavô", nas suas modalidades declarativas e interrogativas totais (respostas sim/não).

Partindo de estudos já realizados acerca do português do Brasil (doravante PB), e em particular sobre as variedades de Salvador, Fortaleza e Rio de Janeiro, pretendemos com este estudo discutir resultados dos falares destas três cidades, e seus padrões melódicos de declarativas e interrogativas. Um dos principais problemas dos estudos comparativos é a disparidade de escolhas metodológicas.

Os dados do AMPER são dados de fala controlada, experimental ou de laboratório. $\mathrm{O}$ estudo das funções prosódicas de segmentação e de hierarquização da fala se faz sobre frases construídas a fim de que variem sistematicamente suas estruturas morfossintáticas, o que permite a oposição de um traço particular entre duas frases, que tenham estruturas iguais (RILLIARD, 2011). Esta função de demarcação e de hierarquização da fala é uma hipótese clássica sobre as funções da prosódia que se encontra descrita em Rossi (1987), Reis (1995), Vaissière (1997) ou Ladd (2008) e nós nos afiliamos a esta abordagem teórica. Os dados que coletamos e analisamos para o AMPER-Por (Brasil) nas três capitais (Rio de Janeiro, Fortaleza e Salvador) podem ser considerados como dados de fala lida ou fala atuada, de acordo com as diferentes condições de produção e oralização dos enunciados, e de acordo com as diferentes conceitualizações teóricas de fala lida, atuada ou espontânea.

${ }^{1}$ O projeto AMPER (Atlas Multimédia Prosodique de l'Espace Roman - Atlas Multimídia Prosódico do Espaço Românico) é coordenado por Michel Contini do Centro de Dialectologia da Universidade de Grenoble, na França e visa contemplar línguas românicas, tais como o italiano, o francês, o castelhano e o galego, além das variedades do português europeu (PE) e do português brasileiro (PB). A pesquisa relativa à variação prosódica do Português é coordenada pela Lurdes de Castro Moutinho, do Centro de Investigação de Línguas e Culturas da Universidade de Aveiro. AMPER-POR disponível em: http://pfonetica.web.ua.pt/AMPER-POR.htm. 
Segundo Gomes da Silva (2014, p. 55-56), a primeira característica de um texto espontâneo, tal como sugere Blanche Benveniste (1998), é que este nunca é uma produção acabada e que na sua oralização deixa ver suas etapas de produção. A segunda característica é que na fala espontânea aparecem comentários sobra a escolha do léxico e a dificuldade de encontrar a palavra adequada. A terceira característica é que, nesse tipo de discurso, as tentativas lexicais são conservadas, uma vez que não é possível apagar o que se acaba de dizer. A fala espontânea pode apresentar titubeios, repetições, falsos começos. A fala espontânea além de não apresentar uma sequência linear, sintagmática, de uma seleção em ausência, está constituída por relações paradigmáticas, expostas, em presença. $\mathrm{O}$ falante vai e volta, sobre sintagmas já apresentados, seja para corrigi-los ou completá-los, acrescentando comentários ou aspectos que considere relevantes, de uma forma que poderíamos definir como um modo online, ou "sobre la marcha", como foi traduzido em espanhol. Trata-se de uma produção simultânea à sua oralização, no que diverge da fala lida ou atuada.

Ao contrário da fala espontânea, na fala lida ou atuada, seja experimental ou não, o texto já está pronto e é oralizado a posteriori. Na fala atuada, o texto é aprendido de cor e praticado a fim de conseguir uma performance de interação, com efeitos expressivos controlados. Na fala lida o texto está pronto e é oralizado a posteriori, mas diferentemente da fala atuada o texto não é aprendido de cor. As fronteiras podem ser sempre tênues e dependem dos gêneros e eventos de interação. No caso dos dados do AMPER, o falante tem o texto pronto, mesmo que não seja com palavras, mas com imagens sob os olhos, portanto estaríamos mais inclinados a considerá-los como dados de leitura, são frases muito controladas quanto à sua estrutura sintática e fonética que são por sua vez oralizadas sem contexto de interação. Neste estudo comparamos durante nossa análise dados do AMPER aos do projeto ALIB (Atlas Linguístico do Brasil) ${ }^{2}$ para as três capitais. No caso dos dados do ALIB, o falante é apresentado a

${ }^{2}$ O Projeto “Atlas Linguístico do Brasil” foi criado em 1996, sob a coordenação de um Comitê Nacional, presidido pela Professora Doutora Suzana Cardoso, da Universidade Federal da Bahia. O ALIB, mais especificamente, se constitui pela recolha de dados em 250 localidades, tanto nas capitais dos estados como outras cidades de grande e médio porte, linguisticamente representativas. Com relação aos informantes, foram gravados um total de 1100 informantes. Para a coleta dos dados, o Projeto ALIB conta com um inquérito composto por três questionários: (i) Questionário Morfossintático (QMS); (ii) Questionário Semântico-Lexical (QSL) e (iii) Questionário Fonético-Fonológico 
uma situação, a um contexto no qual ele tem que inserir a frase esperada ou proposta com certa intencionalidade. Consideramos que no ALIB os dados coletados são de fala atuada. ${ }^{3}$ Os falantes do ALIB seguem um questionário que inclui questões para a apuração de diferenças prosódicas relativas à natureza das frases. Como exemplo desses contextos de interação, apresentamos aqui os contextos de coleta das interrogativas. São apresentados 4 contextos, com instruções e respostas esperadas para as interrogativas, os dois primeiros para interrogativas disjuntivas e os dois últimos para interrogativas totais (CUNHA, 2005):

1) Ó, meu amigo, você prefere vinho ou cerveja? (Resposta Esperada) Se você/o(a) senhor(a) quer oferecer uma bebida a um amigo e quer saber se ele prefere vinho ou cerveja, como é que você/o(a) senhor(a) se dirige a ele e pergunta? (Instrução)

2) Ó, meu amigo, você toma leite ou café? (Resposta Esperada)

Se você/o(a) senhor(a) quer saber se o seu amigo toma leite ou café, como é que você/o(a) senhor(a) se dirige a ele e pergunta? (Instrução)

3) Você vai sair hoje? (Resposta Esperada)

Se você/o(a) senhor(a) quer saber se alguém vai sair hoje, como é que você/o(a) senhor(a) pergunta? (Instrução)

4) Eu vou sair hoje, doutor? (Resposta Esperada)

Uma pessoa está internada em um hospital e quer saber do médico se vai sair naquele dia. Como é que pergunta? (Instrução)

(QFF), que inclui questões para apuração de diferenças prosódicas, relativas à natureza das frases, que podem ser interrogativas, afirmativas ou imperativas.

${ }^{3}$ Tanto nos dados do AMPER quanto nos dados do ALIB, há "surpresas" na coleta de dados. Mesmo que o texto esteja pronto, no AMPER há falantes que não produzem os artigos ou que mudam as estruturas, razão pela qual se coletam seis de cada enunciado. Em alguns casos, itens lexicais inesperados podem aparecer. Imagens são interpretáveis, mas só são consideradas e selecionadas as frases que reproduzam o modelo ou mais se aproximem em número de sílabas ao modelo esperado. Também no ALIB, Cunha (2005) observa que não se produzem as frases esperadas, quase nunca, na interação de fala atuada. 
Para as declarativas, são apresentados 3 contextos diferentes, com instruções e respostas esperadas, o primeiro para declarativa neutra e os dois últimos para declarativas com marcas de expressividade (CUNHA, 2006). No entanto, Silvestre (2012, p. 59) sinaliza que, além de ter apenas uma questão concernente à declarativa neutra, os informantes não produziram de maneira satisfatória as informações desejadas e, ao contrário do esperado, não houve a possibilidade de comparar frases idênticas ou, ao menos, terminadas pelo mesmo vocábulo. Por essa razão, em seu trabalho, Silvestre (2012) compara enunciados declarativos neutros produzidos ao longo dos demais questionários.

\section{1) Você vai sair hoje. (Resposta Esperada)}

Uma pessoa está internada num hospital e quer saber do médico se vai sair naquele dia. Se a resposta for positiva, como é que o médico responde? (Instrução)

2) Oh, gente, estou muito aborrecido com o que aconteceu. (Resposta Esperada, expressando desagrado, rispidez)

Você / o(a) senhor(a) quer dizer a algumas pessoas que estão presentes que você / o(a) senhor(a) está muito aborrecido com o que aconteceu. Como é que você / o(a) senhor(a) diz? (Instrução)

3) Oh, gente, estou muito feliz com o resultado do trabalho. (Resposta Esperada, expressando contentamento, polidez)

Você / o(a) senhor(a) quer dizer a algumas pessoas que estão presentes que você / o(a) senhor(a) está muito feliz com o resultado do trabalho. Como é que você / o(a) senhor(a) diz? (Instrução)

As estruturas comparadas são próximas e têm em geral o mesmo número de sílabas, tanto no projeto AMPER quanto no ALIB, que utiliza dados de entrevista e enunciados paroxítonos. Entretanto, consideramos que os dados do ALIB são de fala atuada os dados do AMPER são de fala lida, sendo ambos experimentais.

Esta comparação da variação prosódica de enunciados do AMPER Por (Brasil), referentes a três capitais brasileiras, tem quatro objetivos: 1) caracterizar o padrão declarativo e interrogativo total de Salvador, Fortaleza e Rio de Janeiro verificando se os acentos tonais $\mathrm{H}+\mathrm{L} * \mathrm{~L} \%$ para as sílabas nucleares das declarativas e $\mathrm{L}+\mathrm{H}^{*} \mathrm{~L} \%$ para as sílabas nucleares das interrogativas, propostos por Moraes (2008) se realizam 
com estes dados do projeto AMPER; ${ }^{4} 2$ ) discutir os resultados referentes às duas capitais, Salvador e Fortaleza, de acordo com o trabalho de Lira (2009) que analisou dados dessas capitais; 3) comparar os resultados do AMPER aos resultados da análise de dados do projeto ALIB propostos por Silva (2011) e Silvestre (2012) para as três capitais; 4) descrever a variação da sílaba tônica com relação às sílabas pretônica e postônica nucleares em termos de duração, de frequência fundamental e de intensidade, comparando convergências e divergências de implementação destes parâmetros acústicos nas três variedades locais analisadas. Para a realização deste estudo, seguimos os padrões comparativos propostos por Moraes (2008) para o estado do Rio de Janeiro, os de Antunes (2012) para o estado de Minas Gerais, os de Nunes (2015) para o estado de Santa Catarina e os de Seara e Rebollo-Couto (2011) para dados comparados de Santa Catarina e Rio de Janeiro, considerando ainda a discussão proposta por Lira (2009) com relação à variação entonacional em cinco capitais da região nordeste.

\section{Pesquisas anteriores sobre os enunciados declarativos e interrogativos totais}

Para as descrições de contornos declarativos e interrogativos totais, Moraes (2008) propõe dois acentos tonais nucleares contrastantes. A inflexão final apresenta um movimento final descendente $(\downarrow)$ nas modalidades assertivas, exclamativas e interrogativas parciais, ou ainda com final circunflexo $\left({ }^{\wedge}\right)$, ou seja, descendente-ascendente-descendente, na modalidade interrogativa total. Seguindo a notação métrica autossegmental, Moraes (2008) propõe enunciados declarativos neutros com um padrão melódico $\mathrm{H}+\mathrm{L} * \mathrm{~L} \%$, ou seja, uma queda entre as sílabas finais pretônica e tônica, seguido de um nivelamento na postônica. Para os enunciados interrogativos totais neutros, propõe a notação $\mathrm{L}+\mathrm{H}^{*} \mathrm{~L} \%$, com diferenças de implementação segundo o alinhamento do pico na tônica, tardio para as perguntas e adiantado para os pedidos. Vale ressaltar que, segundo Cunha (2000), esses acentos podem variar de acordo com

\footnotetext{
${ }^{4}$ De acordo com a teoria métrica autossegmental a notação $(*)$ corresponde à sílaba tônica lexical e a notação (\%) ao tom de fronteira do enunciado. O núcleo é a última sílaba tônica do enunciado, e o pré-núcleo tudo o que está à sua esquerda. O núcleo é portanto o final do enunciado, marcado pelo último acento lexical $(*)$ e o tom de fronteira $(\%)$.
} 
a área dialetal a que pertence o falante. $\mathrm{O}$ par contrastante de acentos tonais (pitch accent) para o $\mathrm{PB}$, entre as declarativas $\mathrm{H}+\mathrm{L} * \mathrm{~L} \%$ e as interrogativas totais neutras $\mathrm{L}+\mathrm{H}^{*} \mathrm{~L} \%$ propostos por Moraes (2008), tem sido sistematicamente encontrado em diversos estudos entonacionais e em diversos pontos do país.

Particularmente com relação às descrições do Rio de Janeiro, nos interessa destacar os resultados obtidos por Silva (2011) e Silvestre (2012), trabalhando com os dados do projeto ALIB. Para Silvestre (2012, p. 82-83):

Rio de Janeiro. A entoação nos enunciados assertivos neutros cariocas, já amplamente descritos no PB, apresentou em nosso corpus o mesmo comportamento outrora evidenciado por Moraes, Cunha, Tenani e outros autores: tom baixo nas sílabas que compõem o acento prénuclear e tons semelhantemente baixos observados até a última sílaba pretônica de I, na qual a F0 alcança o seu pico e posteriormente apresenta o movimento descendente final. O enunciado "O sol tá nascendo", dito pela falante carioca da primeira faixa etária, jovem, dá, mais uma vez, amostra do padrão. Nele, a F0 de $157 \mathrm{~Hz}$ na primeira sílaba tônica de I ascende $14 \%$ até alcançar o pico de $179 \mathrm{~Hz}$ na última sílaba pretônica e decrescer $22 \%$ até a fronteira final.

E Silva (2011, p. 102-103) encontra duas variantes do mesmo padrão para as interrogativas totais na capital do Rio de Janeiro:

A questão total da capital fluminense apresentou, em geral, a seguinte configuração inicial: pico inicial hospedado na primeira sílaba tônica, seguido de declinação ao longo do interior da frase. A configuração circunflexa final apresentou dois tipos de comportamento na tônica final: pico melódico [+ antecipado] seguido de movimento descendente e movimento ascendente seguido de pico melódico [+ atrasado]. Ambos alcançam valores que superam os obtidos pelo primeiro pico. Os enunciados "A pessoa que tá internada vai sair hoje?" e "A minha alta vai ser hoje?", apresentados a seguir, foram produzidos, respectivamente, pelo homem e pela mulher da primeira faixa etária. $\mathrm{O}$ contorno inicial comum a ambos apresenta pico inicial na primeira sílaba tônica, seguidos de movimento descendente que no primeiro enunciado, 
apresenta variação de $36 \mathrm{~Hz}$ e na segunda, de $21 \mathrm{~Hz}$. A diferença entre essas frases é relativa à manifestação do pico da última sílaba tônica. Na primeira frase, observase um movimento de subida cujo ápice é atingido à direita dessa sílaba. Na segunda frase, por outro lado, o pico ocorre no início da tônica, sendo sucedido por um movimento descendente.

Ou seja, os trabalhos de Silva (2011) e Silvestre (2012) confirmam a proposta de Moraes (2008) para o Rio de Janeiro. E no caso de Salvador e Fortaleza? No caso dessas duas capitais do Nordeste contamos com os resultados de Lira (2009), cujos dados são neste artigo reanalisados em função da comparação com o Rio de Janeiro, considerando, além do contorno melódico analisado na tese de Lira (2009), variações de F0, duração e intensidade.

Lira (2009) analisa apenas os enunciados interrogativos totais e parciais, de Salvador e Fortaleza. No que diz respeito aos contornos melódicos das questões totais nessas duas capitais, a autora propõe dois padrões contrastantes para as duas variedades regionais. A proposta é de uma tônica final alta seguida de postônicas baixas para Fortaleza, e inversamente, de uma tônica final baixa, seguida de postônica alta em Salvador, movimento ascendente que se inicia já na sílaba tônica (LIRA, 2009, p. 106-107)

Essa tônica final baixa para Salvador, mas com movimento já ascendente e pico nas postônicas é exemplificada, nos três padrões acentuais, da seguinte forma para os interrogativos totais de Salvador (LIRA, 2009, p. 101-106):

a) O final oxítono termina em movimento ascendente "bisavô" com pequeno apêndice sobre a tônica final (2009, p. 104).

b) O final paroxítono, "Renato", com a perda da última sílaba, também termina como o padrão oxítono com uma subida melódica moderada na sílaba tônica, de 98 a $129 \mathrm{~Hz}$ considerando os valores médios de realização de um falante (2009, p. 104).

c) E o final proparoxítono, "pássaro", termina ora com um movimento ascendente sobre a tônica final que se prolonga sobre as postônicas finais, ora com uma sílaba tônica final que se situa em um nível alto, mas seguido de uma queda sobre a postônica final (2009, p. 106). 
Essa tônica final alta para Fortaleza é exemplificada nos três padrões acentuais, da seguinte forma para os interrogativos totais de Fortaleza (LIRA, 2009, 9 p. 4-96), sendo os padrões oxítono e paroxítono bem próximos em oposição ao proparoxítono:

a) O final oxítono, "bisavô", termina com uma subida melódica mais nítida na sílaba tônica, de 96 a $124 \mathrm{~Hz}$, considerando os valores médios de realização de um falante (2009, p. 95).

b) O final paroxítono, "Renato", com a perda da última sílaba, também termina com uma subida melódica moderada na sílaba tônica, de 96 a $105 \mathrm{~Hz}$ considerando os valores médios de realização de um falante (2009, p. 94).

c) E, o final proparoxítono, "pássaro", termina com uma subida melódica após a tônica final, que passa de 124 a $130 \mathrm{~Hz}$ e chega a $180 \mathrm{~Hz}$ na última postônica final, considerando os valores médios de realização de um falante, sem supressão das últimas sílabas átonas, e com pico na ultima átona $(2009$, p. 96)

Silva (2011), em pesquisa utilizando o corpus do projeto ALIB, analisa os enunciados interrogativos com final paroxítono ("O meu amigo vai ter alta hoje?"; "Você vai sair hoje?" e "A minha alta vai ser hoje?").

Para Salvador, Silva (2011, p. 93-94) encontra dois padrões, um padrão de tônica alta seguida de postônica baixa, que corresponde ao acento proposto por Moraes (2008) L + H* L\% mas também um acento com um tom de fronteira alto $\mathrm{L}+\mathrm{H}^{*} \mathrm{H} \%$, que foi o padrão encontrado por Lira (2009), tônica alta seguida de postônica alta:

$\mathrm{O}$ traçado inicial mais comum encontrado nas frases analisadas de Salvador apresenta nível alto na tônica, que também pode ser manifestado na pretônica, seguido de movimento descendente que se alonga até a pretônica final. Em relação ao contorno do final da frase, foram encontrados dois comportamentos: uma configuração circunflexa formada por F0 baixa na pretônica, subida melódica com pico alinhado à direita na tônica e descida na postônica; e um movimento ascendente final, hospedado nas sílabas tônica e postônica. Nos dados analisados de Salvador, o segundo pico apresenta-se mais proeminente que o primeiro. 
O enunciado "Você vai sair hoje?", [vo 'se 'vaj sa 'i 'o $3 i$ ], produzido pela falante mulher da segunda faixa etária, apresenta o padrão que foi mais recorrente nos dados analisados de Salvador. Nessa frase, o nível mais alto da frase recai sobre a primeira tônica. Um movimento descendente de $54 \mathrm{~Hz}$ ocupa o interior do enunciado. $\mathrm{Na}$ sílaba tônica, a frequência aumenta $50 \mathrm{~Hz}$ em direção ao final da sílaba, onde alcança seu pico, decrescendo $34 \mathrm{~Hz}$ na postônica.

No enunciado "Eu estou de alta?", [ew if 'to dzi 'aw te], realizado pela falante mulher da primeira faixa etária, observa-se o padrão melódico menos recorrente nos dados analisados da capital baiana. Essa frase possui pico melódico na pretônica, seguido de movimento descendente de $25 \mathrm{~Hz}$ até a pretônica final e subida de $38 \mathrm{~Hz}$ da F0 na última tônica, que permanece alta na postônica.

Para Fortaleza, Silva (2011, p. 84-85) encontra um padrão de tônica alta seguido de postônica baixa, que corresponde ao acento proposto por Moraes (2008) $\mathrm{L}+\mathrm{H}^{*} \mathrm{~L} \%$, com ensurdecimento sistemático da última sílaba postônica, potencialmente ligado à escolha da unidade lexical "hoje":

Nos enunciados coletados em Fortaleza, foi observado um único padrão de questão total. A primeira configuração da frase apresenta movimento descendente que se espraia desde a primeira até a última pretônica do enunciado. A segunda configuração, por sua vez, caracteriza-se por movimento ascendente-descendente no interior da tônica final, cujo pico possui traço [+ atrasado]. O comportamento da postônica não pôde ser descrito devido ao seu ensurdecimento em todos os dados.

No enunciado "O meu amigo vai ter alta hoje?", [u 'mew ã 'mi gu vaj te 'aw te 'o 31], dito pela falante mulher da primeira faixa etária, constata-se que a proeminência de $216 \mathrm{~Hz}$ do início da frase localiza-se na primeira sílaba pretônica, sendo seguida por um decréscimo de $52 \mathrm{~Hz}$ ao longo das sílabas do interior da frase. A configuração circunflexa final está hospedada na última sílaba tônica, com pico alinhado à sua direita. Essa configuração é menos destacada que a primeira, apresentando variação de 38 $\mathrm{Hz}$ na subida e $19 \mathrm{~Hz}$ na descida da F0. (SILVA, 2011, p. 84-85) 
Silvestre (2012, p. viii), em pesquisa utilizando o mesmo corpus do projeto ALIB, apresenta para todos os enunciados declarativos ("Você vai estar de alta hoje."; "Eu dou alta pra ele." e "O sol está nascendo") e nas três localidades, Salvador, Fortaleza e Rio de Janeiro, um contorno descendente no núcleo, com notação fonológica $\mathrm{H}+\mathrm{L} * \mathrm{~L} \%$, sendo que a diferença entre os contornos do Rio de Janeiro e os do nordeste estariam no ataque, ou pré-núcleo dos enunciados declarativos:

Ao padrão observado nas capitais nortistas e nordestinas, atribui-se a mesma notação que Cunha (2005) propôs para a asserção neutra em Recife, com base no corpus do projeto NURC: $\mathrm{H}^{*} \ldots \mathrm{H}+\mathrm{L} * \mathrm{~L} \%$. Para o padrão majoritariamente observado nas capitais do centro-oeste e do sudeste do Brasil, atribui-se notação semelhante a de Cunha (2005) e Moraes (2008) para a asserção neutra, ambos com base na fala carioca: $\mathrm{L}+\mathrm{H}^{*}$ $\mathrm{H}+\mathrm{L} * \mathrm{~L} \%$. (SILVESTRE, 2012, p. viii)

Os trabalhos de Silva (2011) e Silvestre (2012) utilizam o corpus do ALIB para a análise prosódica dos enunciados interrogativos e declarativos, respectivamente, com o objetivo de caracterizar as diferenças entonacionais entre as capitais brasileiras.

\section{Procedimentos metodológicos}

Para a feitura desse trabalho, adotamos a metodologia empregada pelo Projeto AMPER (MOUTINHO et alii, 2011). O corpus compreende a gravação de uma série de sentenças declarativas e interrogativas totais neutras geradas através de estímulos visuais. Detalhamos a seguir por partes: o corpus de pesquisa, os falantes da pesquisa e apresentação das etapas de análise.

\subsection{O corpus da pesquisa}

O corpus desta análise está composto por 6 enunciados, formados por 3 enunciados declarativos, aqueles que afirmam a realidade ou a possibilidade de um fato, e 3 interrogativos totais, aqueles que correspondem ao caráter afirmativo ou negativo da predicação, ou seja, respondem-se com sim ou não. Os enunciados são analisados a partir de três repetições de cada, chegando a um total de 18 enunciados analisados 
para cada falante. Todos eles possuem 10 sílabas contemplando final proparoxítono, paroxítono e oxítono. Estes enunciados foram obtidos por meio de gravações de três frases, repetidas três vezes por cada falante. A metodologia do AMPER prevê a gravação de 6 repetições dos dados para assim se justificar a escolha das três melhores. As frases são as seguintes, de acordo com seus núcleos paroxítono, paroxítono e oxítono:

- O pássaro gosta do pássaro.

- O Renato gosta do Renato.

-O bisavô gosta do bisavô.
-O pássaro gosta do pássaro?

- O Renato gosta do Renato?

- O bisavô gosta do bisavô?

Escolhemos três frases de cada modalidade produzida por cada falante. Nossos critérios foram: qualidade da gravação (algumas gravações apresentaram problemas técnicos, como por exemplo, enunciado truncado) e com a relação sinal-ruído alta o suficiente para realizar as análises acústicas deste trabalho.

Os programas de análise do AMPER geram uma curva de F0 média, deslexicalizada, a partir das três realizações escolhidas para cada enunciado por falante. A técnica de deslexicalização (RILLIARD, 2014 , p. 30), baseada num processo de ressíntese da curva melódica, sem conteúdo segmental, assegura uma transmissão eficaz da informação prosódica normalizando eventuais efeitos microprosódicos e fonotáticos. A reiteração conserva uma estrutura silábica clara, e, portanto, todas as informações relacionadas à variação rítmica regional. A segmentação foi feita no Praat e a análise com o Matlab. O procedimento está detalhado em Romano et alii (2011).

Os dados foram coletados com a metodologia do projeto AMPER, com os enunciados adaptados para o PB. A gravação dos enunciados se coleta a partir da leitura de imagens. Os falantes recebem estímulos visuais para produzi-los, propostos por Moraes e Abraçado (2005). 
Figura 1 - Exemplos de enunciado (A) declarativo e (B) interrogativo a ser produzido pelos falantes
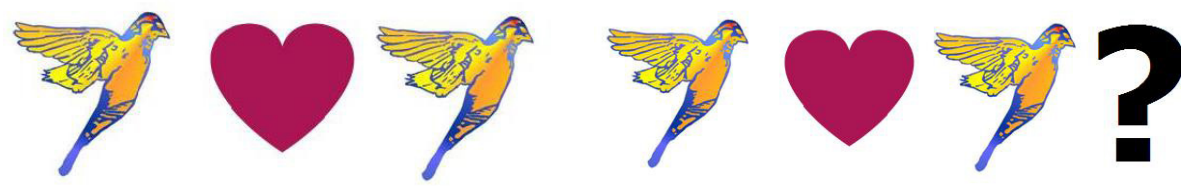

A: O pássaro gosta do pássaro.

B: O pássaro gosta do pássaro?

Uma vez que o texto está pronto, e é oralizado a posteriori, após um período de treinamento e repetição, consideramos que estes dados coletados estão mais próximos aos dados de leitura e não aos dados de fala atuada, como os do projeto ALIB para as capitais brasileiras, coletados a partir de um contexto de interação e com maior controle da expressividade. Em ambos os casos estamos diante de fala experimental (ou de laboratório), gerada a partir de um elemento motivador, mas o fato de que o texto não esteja terminado, e não tenha sido produzido simultaneamente ao seu processo de oralização, nos faz considerar nossos dados como mais próximos aos dados de leitura (o texto está sob os olhos do falante) e não aos de fala atuada (ele já sabe o texto de cor, repetiu e praticou bastante a sua elocução).

\subsection{Falantes da pesquisa}

Os falantes desta pesquisa são originários de três cidades: Salvador e Fortaleza, na região nordeste do Brasil, e Rio de Janeiro, na região sudeste. Todos os 6 falantes, um homem e uma mulher de cada localidade, têm pelo menos nível de escolaridade médio concluído, são todos da categoria "jovens" de 20 a 35 anos. Os falantes do Rio de Janeiro estão no último ano de graduação em Letras, preparando seu TCC, o que pode influenciar no padrão de leitura que encontramos bem marcado para os falantes desta cidade com relação aos das duas capitais do nordeste que não têm nível superior.

Os falares das cidades de Salvador, Fortaleza e Rio de Janeiro são três "sotaques" facilmente reconhecíveis e estereotipados ou difundidos na mídia em todo o Brasil, embora faltem testes de percepção que atestem as condições de reconhecimento desses falares (CUNHA, 2006). Nesse sentido destacamos as pesquisas que começam a ser realizadas na 
UFRJ, sob a orientação de João Antônio de Moraes para a descrição de movimentos melódicos perceptivamente relevantes (MIRANDA, 2015, p. 19) do Português do Brasil. ${ }^{5}$

\subsection{Etapas de análise}

A fase de análise de dados para esta pesquisa foi a segmentação dos enunciados no programa computacional PRAAT (BOERSMA; WEENINK, 2014), a fim de observar o comportamento das vogais tônicas, pretônicas e postônicas dos enunciados, como se implementaram os parâmetros acústicos F0, duração e intensidade de cada uma das vogais dos enunciados produzidos. Posteriormente, geramos gráficos dos parâmetros acústicos: frequência fundamental (F0), intensidade e duração vocálica através de scripts do próprio PRAAT e do programa Interface_AMPER_beta11 (RILLIARD; LAI, 2008), de acordo com as convenções apresentadas em Contini et alii (2009) ou em Romano et alii (2011). A partir desses gráficos fizemos a descrição fonética e a análise fonológica do contorno entonacional dos enunciados. No caso de vogais que não se realizam, a convenção é marcar um valor de F0 igual a $50 \mathrm{~Hz}$ o que faz que a curva pareça descontínua nos traçados e gráficos gerados.

Do ponto de vista fonético, para a realização deste estudo levamos em consideração o valor da duração e da intensidade das vogais do núcleo de cada enunciado (última sílaba acentuada) e da frequência fundamental (F0). A medida de F0 é feita em três pontos de cada vogal, começo meio e fim, introduzindo assim uma normalização temporal comparável à normalização apresentada por Xu (2004) e Arantes (2015). Para obter valores estáveis de cada um destes parâmetros, optamos por considerar a média de três repetições de cada vogal, de acordo com a metodologia AMPER. As variações de intensidade, ligadas às condições de gravação (em particular o nível da gravação e a distância entre o falante e o microfone) são aqui negligenciáveis, uma vez que consideramos, com a metodologia AMPER, as diferenças de nível médio de intensidade entre vogais próximas; essas diferenças são pouco influenciáveis pelas condições de gravação.

\footnotetext{
5 São trabalhos que destacam a entoação modal, através de estudos fonéticos experimentais da entoação do português do Brasil, a partir do método de ressíntese e estilização da curva de F0 em uma abordagem perceptiva baseada no modelo holandês IPO (MIRANDA, 2015).
} 
A duração das vogais é considerada e não a das sílabas ou a das unidades $\mathrm{V}-\mathrm{V}$, o que constitui uma aproximação discutível do ritmo da fala (BARBOSA, 2007), mas as restrições inerentes ao corpus AMPER tornam impossível uma normalização estrita das influências intrínsecas dos fonemas; essas influências são controladas pela utilização das mesmas frases (e, portanto, dos mesmos fonemas), para todos os falantes. Sendo assim, neste trabalho observamos, com esta metodologia, padrões de alongamento e de redução da duração vocálica.

Analisamos o comportamento da F0 das vogais a partir do contraste entre os valores em $\mathrm{Hz}$ da vogal da primeira sílaba tônica e das vogais pretônicas e postônicas de cada enunciado. Do ponto de vista fonológico levamos em consideração o contorno melódico dos enunciados, tais como foram descritos inicialmente por Moraes (2008) e confirmados pelos trabalhos de Lira (2009), Silva (2011) e Silvestre (2012).

\section{Resultados e discussões}

A partir dos gráficos de F0, duração e intensidade, desenvolvemos nossa análise sobre os acentos tonais nucleares dos enunciados de cada localidade, a partir dos três padrões acentuais do português: começamos com o padrão nuclear paroxítono, o mais frequente e produtivo (1 sílaba tônica e 1 átona final), seguido do padrão proparoxítono, o mais longo (1 sílaba tônica e 2 sílabas átonas finais) e do padrão oxítono, o mais polêmico por aparecer truncado ou comprimido segundo as diferentes interpretações fonológicas (1 sílaba final tônica).

\subsection{Resultados e discussões: núcleos paroxítonos}

A categoria acentual paroxítona é a categoria mais frequente do português em termos de produtividade, apresentando, segundo Cintra (1997), uma frequência de distribuição de aproximadamente 70\% em termos de distribuição de padrões acentuais nos vocábulos em português. O padrão acentual das paroxítonas é analisado a partir dos três parâmetros acústicos: F0, duração e intensidade em enunciados declarativos e interrogativos totais.

Em termos de F0, na variedade de Salvador, tanto o homem quanto a mulher realizam nas frases declarativas (em vermelho) um padrão ascendente e alto na pretônica do núcleo, "Renato", sílaba 8 , 
descendente na sílaba tônica, sílaba 9, e baixo na sílaba postônica final, sílaba 10.

Os enunciados interrogativos (em azul) apresentam uma descida da F0 na sílaba pretônica, sílaba 8, uma curva ascendente na tônica, sílaba 9, e um comportamento variável na postônica, baixo/ descendente para a mulher e alto/ ascendente para o homem.

Figura 2 - Variedade de Salvador: escolaridade média

Enunciado 1: O Renato gosta do Renato./ O Renato gosta do Renato?

Declarativas (vermelho) e interrogativas (azul).

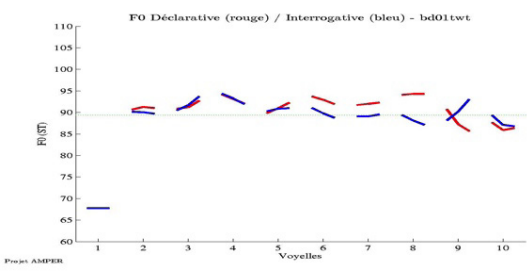

A: F0 da mulher de Salvador

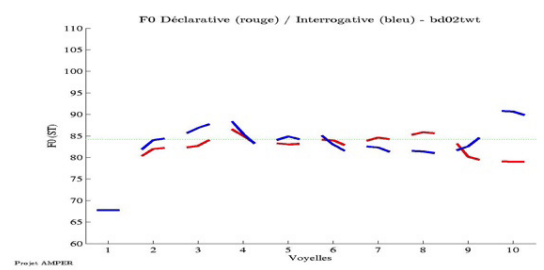

B: F0 do homem de Salvador

As vogais elididas são representadas, por convenção, nos gráficos AMPER com $50 \mathrm{~Hz}$ para a F0 e com 0 (zero) duração e intensidade, portanto, a barra baixa na primeira vogal significa queda do artigo inicial.

No pré-núcleo "Renato", ver sílabas 2, 3 e 4, temos o mesmo comportamento na declarativa e na interrogativa, embora nas interrogativas a F0 seja mais alta no homem: um movimento ascendente que culmina na postônica, uma tônica ascendente e uma postônica alta descendente. Trata-se de um comportamento ascendente progressivo, sem a queda abrupta da F0 na sílaba tônica da declarativa, como se observa no núcleo, sílaba 9 , correspondendo à notação proposta por Silvestre (2012), L + H* como característica dos falares do norte e nordeste. Do ponto de vista fonológico, as duas realizações confirmam o padrão nuclear $\mathrm{H}+\mathrm{L}^{*} \mathrm{~L} \%$ para as declarativas (vermelho), mas só a mulher confirma o padrão nuclear $\mathrm{L}+\mathrm{H}^{*} \mathrm{~L} \%$ para as interrogativas (azul), proposto por Moraes (2008). No homem, o padrão realizado corresponde a $\mathrm{L}+\mathrm{H}^{*}$ H\%, já registrado por Lira (2009) e Silva (2011) para Salvador.

$\mathrm{Na}$ variedade de Fortaleza, tanto o homem quanto a mulher realizam nas frases declarativas (em vermelho) um padrão ascendente e alto na pretônica do núcleo, "Renato", sílaba 8 , descendente na sílaba 
tônica, sílaba 9, e baixo na sílaba postônica final, sílaba 10, elidida pela mulher.

Os enunciados interrogativos (em azul) apresentam uma F0 baixa na sílaba pretônica, sílaba 8 , uma curva ascendente-descendente na tônica, sílaba 9, e uma queda de F0 na sílaba postônica final, tanto para a mulher quanto para o homem.

Figura 3 - Variedade de Fortaleza: escolaridade média

Enunciado 1: O Renato gosta do Renato./ O Renato gosta do Renato?

Declarativas (vermelho) e interrogativas (azul).

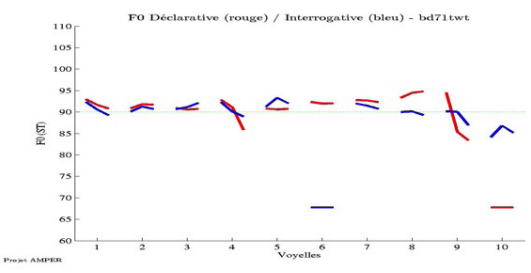

A: F0 da mulher de Fortaleza

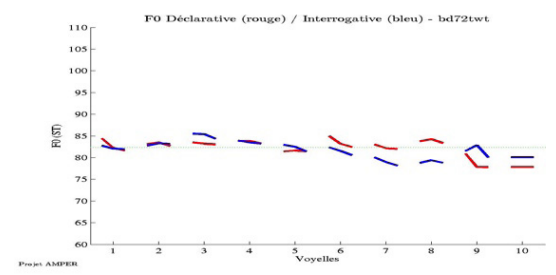

B: F0 do homem de Fortaleza

No pré-núcleo "Renato", ver sílabas 2, 3 e 4, temos o mesmo comportamento na declarativa e na interrogativa: um movimento ascendente que culmina na postônica. Trata-se de um comportamento alto e suavemente ascendente progressivo, sem a queda abrupta da F0 na sílaba tônica da declarativa, como se observa no núcleo, sílaba 9 , não correspondendo à notação proposta por Silvestre (2012), L + H*, como característica dos falares do norte e nordeste, mas sim à notação $\mathrm{H}^{*}$. Do ponto de vista fonológico, as duas realizações confirmam o padrão nuclear $\mathrm{H}+\mathrm{L}^{*} \mathrm{~L} \%$ para as declarativas (vermelho), mas só o homem confirma o padrão nuclear $\mathrm{L}+\mathrm{H}^{*} \mathrm{~L} \%$ para as interrogativas (azul), proposto por Moraes (2008). Na mulher, o padrão realizado corresponde a $\mathrm{H}+\mathrm{H}^{*}$ L\% já registrado por Lira (2009) e Silva (2011) para Fortaleza.

Na variedade de Rio de Janeiro, tanto o homem quanto a mulher realizam nas frases declarativas (vermelho) um padrão ascendente de F0 na pretônica, do núcleo, "Renato", descendente na sílaba tônica e baixo na sílaba postônica que não é elidida. 
Figura 4 - Variedade Rio de Janeiro: escolaridade média

Enunciado 1: O Renato gosta do Renato./ O Renato gosta do Renato?

Declarativas (vermelho) e interrogativas (azul).

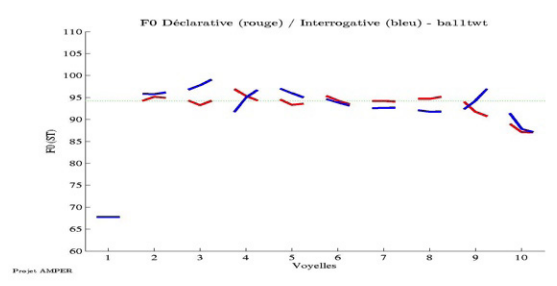

A: F0 da mulher de Rio de Janeiro

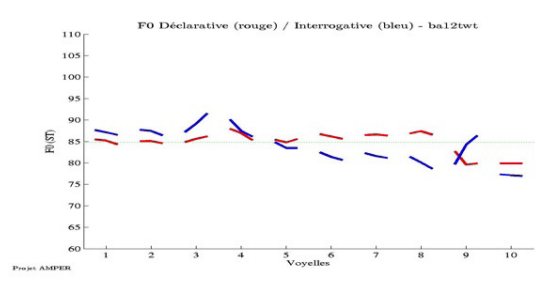

B: F0 do homem de Rio de Janeiro

No pré-núcleo "Renato", o comportamento do padrão é bem diferente do comportamento do núcleo, ver sílabas 2, 3 e 4, corresponde ao acento tonal $\mathrm{H}^{*}$, proposto para Rio de Janeiro por Moraes (2008) e Silvestre (2012). Trata-se de um comportamento ascendente progressivo com pico na postônica nas declarativas, sem a queda abrupta de F0 do núcleo, ver sílabas 8,9 e 10. Do ponto de vista fonológico as duas realizações confirmam o padrão $\mathrm{H}+\mathrm{L} * \mathrm{~L} \%$ para as declarativas (vermelho) e o padrão $\mathrm{L}+\mathrm{H}^{*} \mathrm{~L} \%$ para as interrogativas (azul), proposto por Moraes (2008).

Em termos de duração, a distribuição das durações por sílaba é muito mais regular, com menos diferença entre vogais acentuadas e não acentuadas ou átonas nos dados do Rio de Janeiro, do que nos de Salvador e Fortaleza, para as declarativas (vermelho) e para as interrogativas (azul). 
Figura 5 - Duração de enunciado com núcleo paroxítono: mulheres

Enunciado 1: O Renato gosta do Renato./ O Renato gosta do Renato?

Declarativas (vermelho) e interrogativas (azul).

Duração das mulheres de Salvador, Fortaleza, e Rio de Janeiro ${ }^{6}$
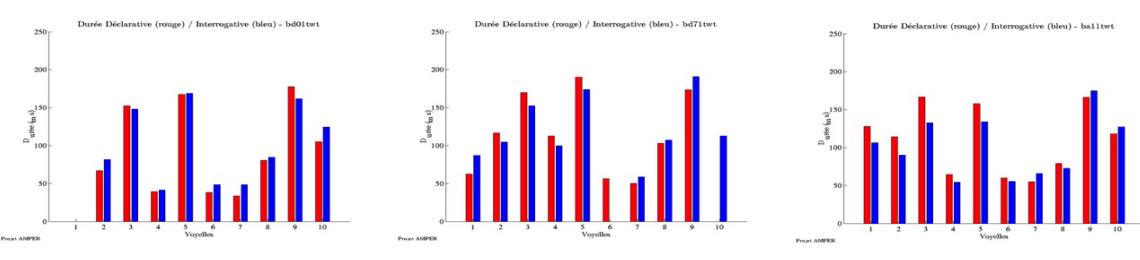

Figura 6 - Duração de enunciado com núcleo paroxítono: homens

Enunciado 1: O Renato gosta do Renato./ O Renato gosta do Renato?

Declarativas (vermelho) e interrogativas (azul).

Duração dos homens de Salvador, Fortaleza, e Rio de Janeiro
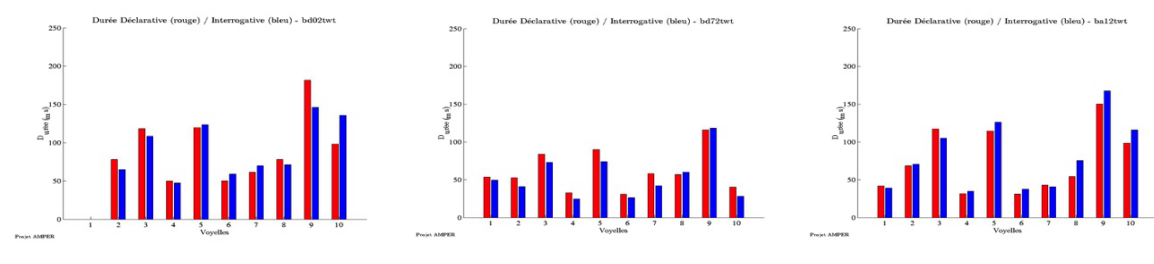

As vogais das sílabas tônicas de "Renato", sílaba 3 no pré-núcleo, "gosta", sílaba 5, e "Renato", sílaba 9 no núcleo do enunciado, são mais longas do que as vogais das sílabas átonas que as sucedem em Fortaleza como no Rio de Janeiro. ${ }^{7}$

No Rio de Janeiro, as sílabas postônicas, 4, 6 e 10 são sempre realizadas, o que pode ser atribuído a um padrão escolar de leitura, aprendido e praticado nos anos de formação e exposição à variante

\footnotetext{
${ }^{6}$ As vogais elididas são representadas, por convenção, nos gráficos AMPER com $50 \mathrm{~Hz}$ para a F0 e com 0 (zero) duração e intensidade. A seleção de frases se faz em função dessa elisão, quando ocorrer, são escolhidas três frases que tenham a vogal elidida no mesmo lugar, caso seja impossível encontrar três frases com os mesmos pontos de elisão selecionam-se apenas duas.

${ }^{7}$ Para uma comparação mais precisa teria sido necessária a normalização da duração das vogais, entretanto, as vogais tônicas são tão mais longas que as átonas, que acreditamos que tal procedimento não deve alterar este padrão.
} 
de leitura frente à fala espontânea. Esse padrão se repete nos dados de Fortaleza, apesar do ensurdecimento e das duas supressões de centros silábicos das átonas, sílaba 6 na declarativa "gosta" e sílaba 10 na declarativa "Renato". Em termos de duração, o padrão mais acentual, com maior diferença entre sílabas átonas e tônicas, é o de Salvador. Trata-se de uma descrição qualitativa e não quantitativa dessa diferença que precisaria ser sistematicamente analisada em trabalhos futuros.

O falante masculino do Rio de Janeiro divide seu enunciado simetricamente em dois grupos rítmicos, com dois picos de duração nas duas tônicas no pré-núcleo, "Renato" e "gosta", sílabas 3 e 5, respectivamente, e com dois picos nas duas últimas sílabas do núcleo, "Renato", sílabas 9 e 10, com alongamento da postônica final, como estratégia rítmica de leitura (na nossa interpretação).

Em termos de intensidade, nas três localidades, a intensidade da sílaba tônica no núcleo é mais importante na interrogativa (azul), sílaba 9, do que na declarativa (vermelho). O comportamento da mulher do Rio de Janeiro se diferencia das demais, neste caso, pela queda abrupta progressiva de intensidade na sílaba átona final do enunciado, sílaba 10, procedimento estratégico característico da leitura que não se verifica nas outras duas falantes.

Figura 7 - Intensidade de enunciado com núcleo paroxítono: mulheres

Enunciado 1: O Renato gosta do Renato./ O Renato gosta do Renato?

Declarativas (vermelho) e interrogativas (azul).

Intensidade das mulheres de Salvador, Fortaleza, e Rio de Janeiro
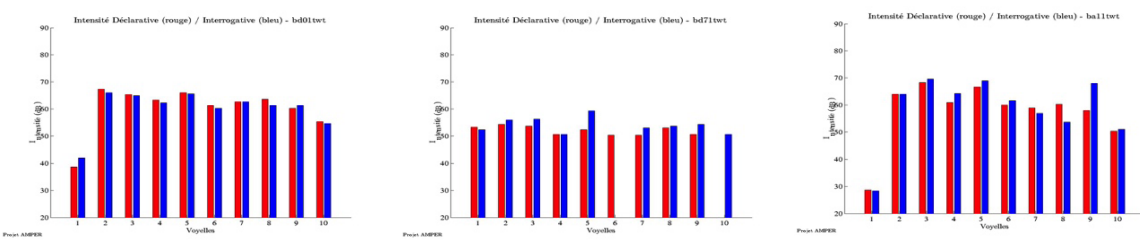
Figura 8 - Intensidade de enunciado com núcleo paroxítono: homens

Enunciado 1: O Renato gosta do Renato./ O Renato gosta do Renato?

Declarativas (vermelho) e interrogativas (azul).

Intensidade dos homens de Salvador, Fortaleza, e Rio de Janeiro
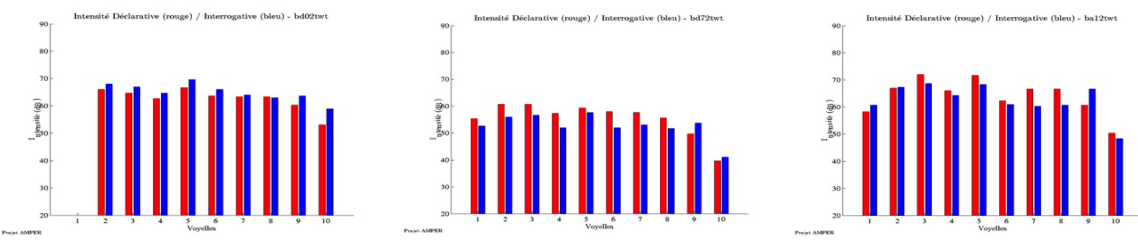

O comportamento do homem do Rio de Janeiro, mais escolarizado, se diferencia das demais, neste caso, pela queda abrupta progressiva de intensidade na sílaba átona final do enunciado, sílaba 10 , procedimento estratégico característico da leitura que não se verifica nos outros dois falantes masculinos.

\subsection{Resultados e discussões: núcleos proparoxítonos}

A categoria acentual proparoxítona é a categoria menos frequente do português em termos de produtividade (REIS, 1995). Considera-se que seja um núcleo mais longo que se estende por três sílabas, quando a última sílaba não for elidida, transformando-se nesse caso num padrão paroxítono. O padrão acentual das proparoxítonas é analisado a partir dos três parâmetros acústicos: F0, duração e intensidade, em enunciados declarativos e interrogativos totais.

Em termos de F0, na variedade de Salvador, nem o homem nem a mulher elidem sílabas finais. Tanto o homem quanto a mulher realizam nas frases declarativas um padrão alto na pretônica, do núcleo, "pássaro", mas descendente na sílaba tônica e baixo na sílaba postônica. 
Figura 9 - Variedade de Salvador: escolaridade média

Enunciado 2: O pássaro gosta do pássaro./ O pássaro gosta do pássaro?

Declarativas (vermelho) e interrogativas (azul).

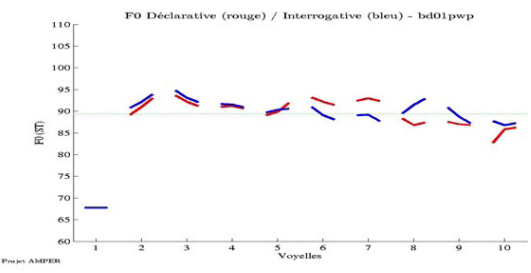

A: F0 da mulher de Salvador

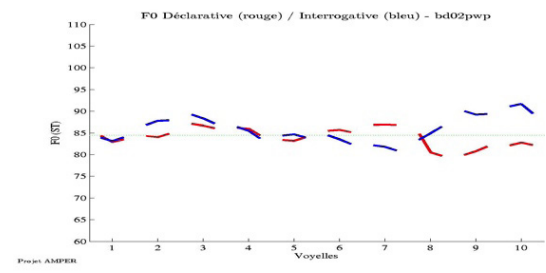

B: F0 do homem de Salvador

No pré-núcleo "pássaro", o comportamento do padrão é bem diferente do comportamento no núcleo, ver sílabas 2,3 e 4, para o prénúcleo. Trata-se de um comportamento alto ou ascendente na sílaba tônica, sílaba 2, sem a queda abrupta de F0 do núcleo, sílaba 8 nas declarativas, tendo um padrão $\mathrm{L}+\mathrm{H}^{*}$ para o pré-núcleo e um padrão $\mathrm{H}$ $+\mathrm{L}^{*} \mathrm{~L} \%$ para o núcleo das declarativas. Nas interrogativas se realizam os dois padrões previstos para Salvador, um com final baixo, $\mathrm{L}+\mathrm{H}^{*} \mathrm{~L} \%$ para a mulher e $\mathrm{L}+\mathrm{H}^{*} \mathrm{H} \%$ para o homem.

Do ponto de vista fonológico as duas realizações confirmam o padrão $\mathrm{H}+\mathrm{L}^{*} \mathrm{~L} \%$ para as declarativas (vermelho) e o padrão $\mathrm{L}+\mathrm{H}^{*}$ L\% para as interrogativas (azul), proposto por Moraes (2008), sendo que no homem se observa a variante descrita por Lira (2009) e Silva (2011) com final alto para Salvador.

$\mathrm{Na}$ variedade de Fortaleza, nem o homem nem a mulher elidem sílabas finais. Tanto o homem quanto a mulher realizam nas frases declarativas (vermelho) um padrão alto na pretônica, do núcleo, "pássaro", alto, mas descendente na sílaba tônica e baixo na sílaba postônica. 
Figura 10 - Variedade de Fortaleza: escolaridade média

Enunciado 2: O pássaro gosta do pássaro./ O pássaro gosta do pássaro?

Declarativas (vermelho) e interrogativas (azul).

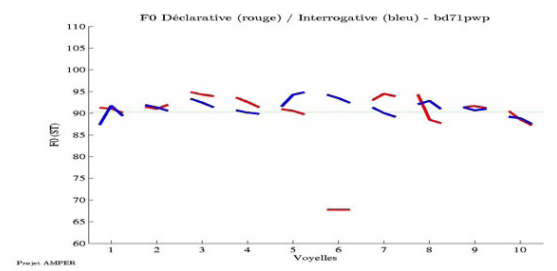

A: F0 da mulher de Fortaleza

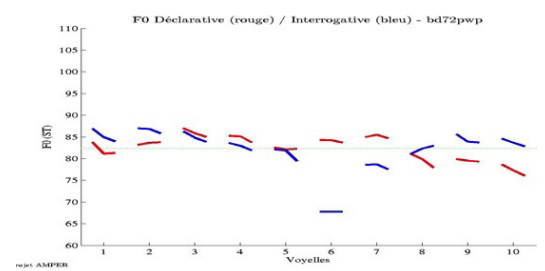

B: F0 do homem de Fortaleza

No pré-núcleo "pássaro", o comportamento do padrão é bem diferente do comportamento no núcleo, ver sílabas 2,3 e 4, para o prénúcleo. Trata-se de um comportamento alto ou ascendente na sílaba tônica, sílaba 2, sem a queda abrupta de F0 do núcleo, sílaba 8 nas declarativas, tendo um padrão $\mathrm{L}+\mathrm{H}^{*}$ para o pré-núcleo e um padrão $\mathrm{H}$ $+L^{*}$ L\% para o núcleo das declarativas. Nas interrogativas (azul), se realizam dois padrões para Fortaleza, um com final baixo, $L+H^{*} L \%$ para a mulher e $\mathrm{L}+\mathrm{H}^{*} \mathrm{H} \%$ para o homem.

Do ponto de vista fonológico, as duas realizações confirmam o padrão $\mathrm{H}+\mathrm{L} * \mathrm{~L} \%$ para as declarativas (vermelho) e o padrão $\mathrm{L}+\mathrm{H}^{*} \mathrm{~L} \%$ para as interrogativas (azul), proposto por Moraes (2008), sendo que no homem também se observa na variedade de Fortaleza a variante descrita por Lira (2009) e Silva (2011) com final alto para Salvador.

Ainda sob o ponto de vista fonológico, as duas realizações confirmam o padrão $\mathrm{H}+\mathrm{L}^{*} \mathrm{~L} \%$ para as declarativas (vermelho) e o padrão $\mathrm{L}+\mathrm{H}^{*} \mathrm{~L} \%$ para as interrogativas (azul), proposto por Moraes (2008). No pré-núcleo "pássaro", o comportamento do padrão é bem diferente do comportamento no núcleo, ver sílabas 2,3 e 4, para o prénúcleo. Trata-se de um comportamento alto ou ascendente na sílaba tônica, sílaba 2, sem a queda abrupta de F0 do núcleo, sílaba 8 nas declarativas, tendo um padrão $\mathrm{L}+\mathrm{H}^{*}$ para o pré-núcleo e um padrão $\mathrm{H}$ $+\mathrm{L}^{*} \mathrm{~L} \%$ para o núcleo das declarativas. Nas interrogativas se realizam os dois padrões previstos para Salvador, um com final baixo, $\mathrm{L}+\mathrm{H}^{*} \mathrm{~L} \%$, para a mulher e $\mathrm{L}+\mathrm{H}^{*} \mathrm{H} \%$ para o homem. Do ponto de vista fonológico, as duas realizações confirmam o padrão $\mathrm{H}+\mathrm{L}^{*} \mathrm{~L} \%$ para as declarativas (vermelho) e o padrão $\mathrm{L}+\mathrm{H}^{*} \mathrm{~L} \%$ para as interrogativas (azul), proposto 
por Moraes (2008), sendo que no homem se observa a variante descrita por Lira (2009) e Silva (2011) com final alto também para Fortaleza.

$\mathrm{Na}$ variedade do Rio de Janeiro, tanto o homem quanto a mulher realizam nas frases declarativas (em vermelho) um padrão alto e ascendente na pretônica do núcleo (sílaba 7), "pássaro", descendente na sílaba tônica, o padrão vai descendo suavemente nas sílabas postônicas que não são elididas.

Figura 11 - Variedade Rio de Janeiro: escolaridade média

Enunciado 2: O pássaro gosta do pássaro./ O pássaro gosta do pássaro?

Declarativas (vermelho) e interrogativas (azul).

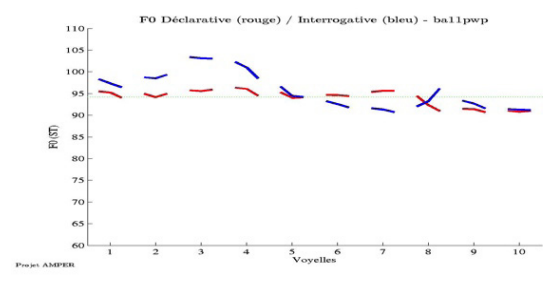

A: F0 da mulher de Rio de Janeiro

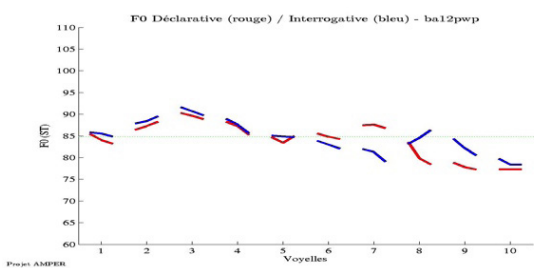

B: F0 do homem de Rio de Janeiro

No pré-núcleo "pássaro", o comportamento do padrão é bem diferente do comportamento no núcleo, ver sílabas 2,3 e 4, para o prénúcleo. Trata-se de um comportamento ascendente na sílaba tônica, sílaba 2, que continua subindo suavemente pelas duas sílabas posteriores, 3 e 4 . Não há apagamento de sílabas e as curvas se realizam progressivamente. Este comportamento rítmico e melódico, tão diferente dos encontrados nos falantes de Salvador e Fortaleza, poderia ser atribuído ao nível diferenciado de escolaridade e formação destes dois falantes. Ambos demonstram ter adquirido um padrão de leitura rítmico, bem como padrões melódicos mais regulares para a oralização dos dados de leitura.

Do ponto de vista fonológico as duas realizações confirmam o padrão $\mathrm{H}+\mathrm{L}^{*} \mathrm{~L} \%$ para as declarativas (vermelho) e o padrão $\mathrm{L}+\mathrm{H}^{*}$ L\% para as interrogativas (azul), proposto por Moraes (2008).

Em termos de duração, nas proparoxítonas se repete o mesmo padrão de supressão silábica para Fortaleza. Entretanto, tanto Salvador como Fortaleza apresentam maior diferença entre as sílabas tônicas e átonas no pré-núcleo "pássaro" - sílabas 2, 3, 4-e "gosta" - sílabas 5 e 6 - do que o Rio de Janeiro. Estas observações rítmicas qualitativas 
precisariam ser sistematicamente descritas posteriormente a partir de uma análise quantitativa.

Figura 12 - Duração de enunciado com núcleo proparoxítono: mulheres

Enunciado 2: O pássaro gosta do pássaro./ O pássaro gosta do pássaro?

Declarativas (vermelho) e interrogativas (azul).

Duração das mulheres de Salvador, Fortaleza, e Rio de Janeiro:
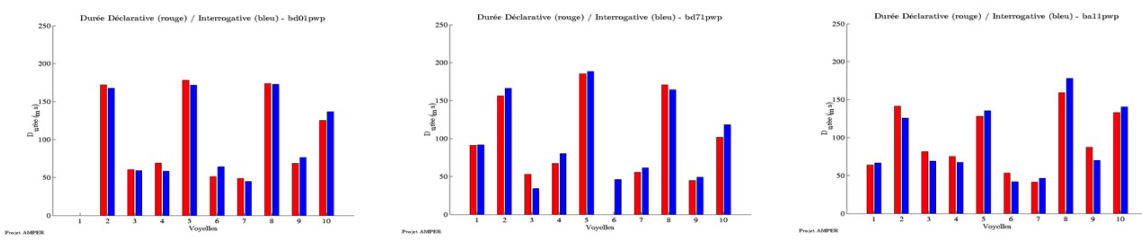

Figura 13 - Duração de enunciado com núcleo proparoxítono: homens

Enunciado 2: O pássaro gosta do pássaro./ O pássaro gosta do pássaro?

Declarativas (vermelho) e interrogativas (azul).

Duração dos homens de Salvador, Fortaleza, e Rio de Janeiro:
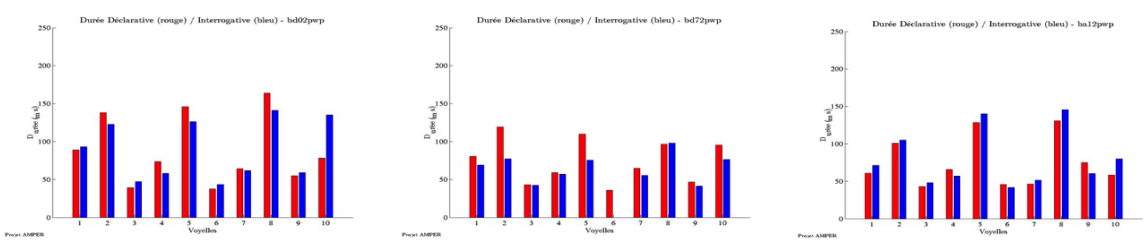

Nas proparoxítonas se repete o mesmo padrão de supressão silábica nos falantes homens de Salvador e Fortaleza frente ao padrão do homem do Rio de Janeiro, que apresenta menos diferença de duração entre tônicas e átonas, com um contorno mais proporcional.

Em termos de intensidade, o planejamento da leitura com a queda abrupta de intensidade no final do enunciado também se realiza no padrão proparoxítono da falante do Rio de Janeiro. 
Figura 14 - Intensidade de enunciado com núcleo proparoxítono: mulheres

Enunciado 2: O pássaro gosta do pássaro./ O pássaro gosta do pássaro?

Declarativas (vermelho) e interrogativas (azul).

Intensidade das mulheres de Salvador, Fortaleza, e Rio de Janeiro:
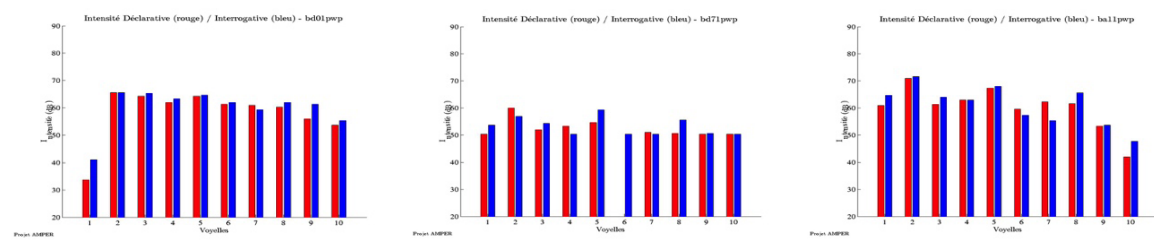

Figura 15 - Intensidade de enunciado com núcleo proparoxítono: homens

Enunciado 2: O pássaro gosta do pássaro./ O pássaro gosta do pássaro?

Declarativas (vermelho) e interrogativas (azul).

Duração dos homens de Salvador, Fortaleza, e Rio de Janeiro:
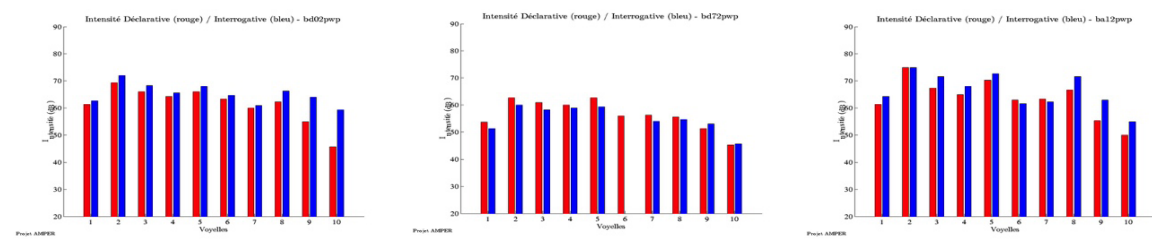

Nas localidades Salvador e Rio de Janeiro, a sílaba tônica das proparoxítonas, sílaba 8 do núcleo, a intensidade da interrogativa (azul) é maior do que a da declarativa (vermelho). Em Fortaleza, a mulher repete o comportamento das outras duas localidades, mas, no homem, a intensidade da declarativa é maior que a da interrogativa.

O planejamento da leitura com a queda abrupta progressiva de intensidade no final do enunciado também se realiza no padrão proparoxítono do falante do Rio de Janeiro.

\subsection{Resultados e discussões: núcleos oxítonos}

A categoria acentual oxítona é a categoria mais polêmica do português em termos de classificação ou atribuição acentual para o núcleo, que pode ser interpretado como um padrão truncado ou comprimido. $\mathrm{O}$ padrão acentual das oxítonas é analisado a partir dos três parâmetros 
acústicos: F0, duração e intensidade em enunciados declarativos e interrogativos totais.

Em termos de F0, na variedade de Salvador, tanto o homem quanto a mulher realizam nas frases declarativas um tom alto na pretônica do núcleo, "bisavô", ver sílaba 9 (em vermelho). A última sílaba tônica é descendente, sendo mais baixa que a pretônica. Isso confirma o acento tonal proposto para o núcleo das declarativas por Moraes (2008), sem o tom de fronteira, em $\mathrm{H}+\mathrm{L}^{*} \mathrm{~L} \%$ de declarativas.

Figura 16 - Variedade de Salvador: escolaridade média

Enunciado 3: O bisavô gosta do bisavô./ O bisavô gosta do bisavô?

Declarativas (vermelho) e interrogativas (azul).

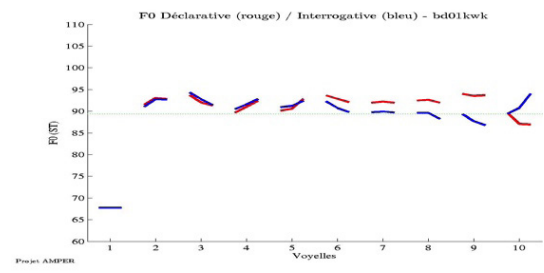

A: F0 da mulher de Salvador

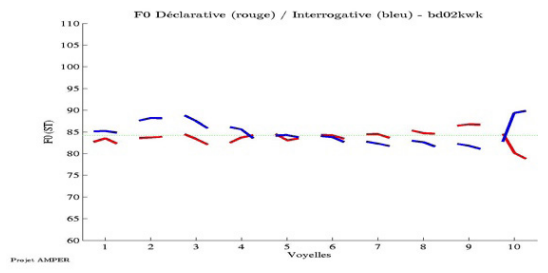

B: F0 do homem de Salvador

No pré-núcleo o comportamento do padrão é bem diferente do comportamento do núcleo, ver sílabas 2,3 e 4 . Trata-se de um comportamento alto ou ascendente progressivo, sem a queda do núcleo. Nas interrogativas o padrão também pode ser considerado como truncado, uma vez que temos uma pretônica baixa, sílaba 9 em azul, seguida de uma tônica alta, sílaba 10. O padrão proposto por Moraes (2008) para o núcleo das interrogativas totais $\mathrm{L}+\mathrm{H}^{*} \mathrm{~L} \%$ se realiza sem o tom de fronteira baixo, pois na nossa interpretação não há segmento posterior para a realização do tom baixo de fronteira $\mathrm{L} \%$, terminando numa sílaba acentuada alta $\mathrm{H}^{*}$, por truncamento.

$\mathrm{Na}$ variedade de Fortaleza, tanto o homem quanto a mulher realizam nas frases declarativas um tom alto na pretônica do núcleo, "bisavô", ver sílaba 9 (em vermelho). Aúltima sílaba tônica é descendente, sendo mais baixa que a pretônica. Isso confirma o acento tonal proposto para o núcleo das declarativas por Moraes (2008) H + L* L\%. 
Figura 17 - Variedade de Fortaleza: escolaridade média

Enunciado 3: O bisavô gosta do bisavô./ O bisavô gosta do bisavô?

Declarativas (vermelho) e interrogativas (azul).

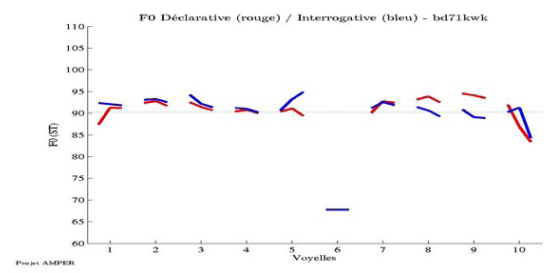

A: F0 da mulher de Fortaleza

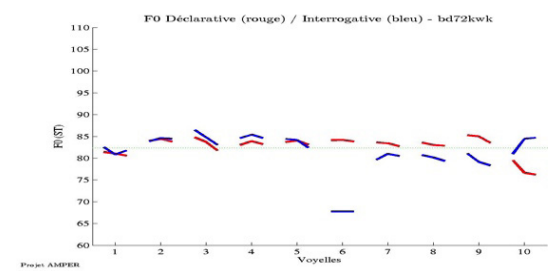

B: F0 do homem de Fortaleza

No pré-núcleo o comportamento do padrão é bem diferente do comportamento do núcleo, ver sílabas 2,3 e 4 . Trata-se de um comportamento alto $\mathrm{H}^{*}$, sem a queda longa e inclinada do núcleo. Nas interrogativas o padrão também pode ser considerado como comprimido, uma vez que temos uma pretônica baixa, sílaba 9 em azul, seguida de uma tônica alta, sílaba 10, ascendente-descendente para a mulher e ascendente com um princípio de descida para o homem. O padrão proposto por Moraes (2008) para o núcleo das interrogativas totais L + $\mathrm{H}^{*} \mathrm{~L} \%$ se realiza com o tom de fronteira baixo para a mulher, mas não para o homem que termina numa sílaba alta, conforme o assinalado por Lira (2009, p. 95), para o padrão oxítono de Fortaleza, por truncamento ou compressão.

Na variedade do Rio de Janeiro, tanto o homem quanto a mulher realizam nas frases declarativas um tom alto descendente na pretônica do núcleo, "bisavô", ver sílaba 9 (em vermelho), sendo esta pretônica o pico do enunciado. A última sílaba tônica é descendente, sendo mais baixa que a pretônica. Isso confirma o acento tonal proposto para o núcleo das declarativas por Moraes (2008), sem o tom de fronteira, em $\mathrm{H}+\mathrm{L} *$ L\% implementando-se a descida na tônica quando esta é a última sílaba do enunciado. 
Figura 18 - Variedade Rio de Janeiro: escolaridade média

Enunciado 3: O bisavô gosta do bisavô./ O bisavô gosta do bisavô?

Declarativas (vermelho) e interrogativas (azul).

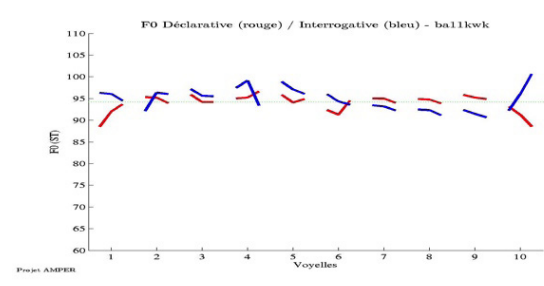

A: F0 da mulher de Rio de Janeiro

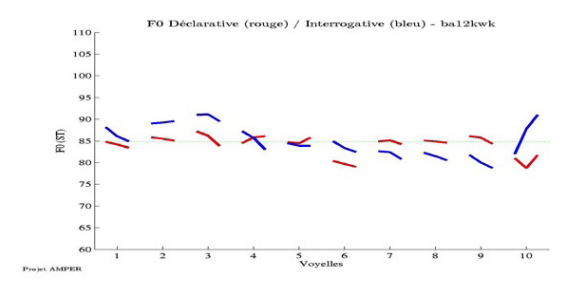

B: F0 do homem de Rio de Janeiro

No pré-núcleo o comportamento do padrão é bem diferente do comportamento do núcleo, ver sílabas 2, 3 e 4 . Trata-se de um comportamento alto ou ascendente progressivo, sem a queda do núcleo. Nas interrogativas o padrão também pode ser considerado como truncado, uma vez que temos uma pretônica baixa, sílaba 9 em azul, seguida de uma tônica alta, sílaba 10 . O padrão proposto por Moraes (2008) para o núcleo das interrogativas totais $\mathrm{L}+\mathrm{H}^{*} \mathrm{~L} \%$ se realiza sem o tom de fronteira baixo, pois na nossa interpretação não há segmento posterior para a realização do tom baixo de fronteira $\mathrm{L} \%$, terminando numa sílaba acentuada alta $\mathrm{H}^{*}$, por truncamento.

Em termos de duração, a duração das vogais tônicas nucleares tende a ser mais longa nas sílabas tônicas das interrogativas (azul) do que nas declarativas (vermelho), pelo menos nos dados de Salvador e Fortaleza, mas não nos do Rio de Janeiro. O mesmo comportamento de duração se encontra nos homens, o falante de Fortaleza é o que mais tende à supressão silábica, sendo que nos três casos a distribuição dos padrões de redução ou alongamento da duração vocálica em dois grupos rítmicos simétricos aponta para uma oralização mais planejada das frases lidas. 
Figura 19 - Duração de enunciado com núcleo oxítono: mulheres

Enunciado 3: O bisavô gosta do bisavô./ O bisavô gosta do bisavô?

Declarativas (vermelho) e interrogativas (azul).

Duração das mulheres de Salvador, Fortaleza, e Rio de Janeiro
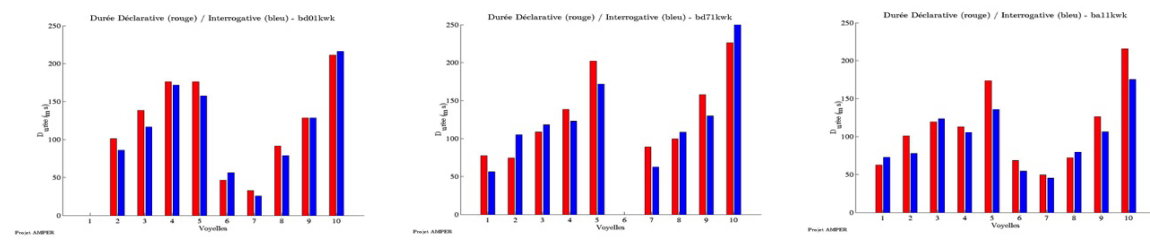

Figura 20 - Duração de enunciado com núcleo oxítono: homens

Enunciado 3: O bisavô gosta do bisavô./ O bisavô gosta do bisavô?

Declarativas (vermelho) e interrogativas (azul).

Duração dos homens de Salvador, Fortaleza, e Rio de Janeiro
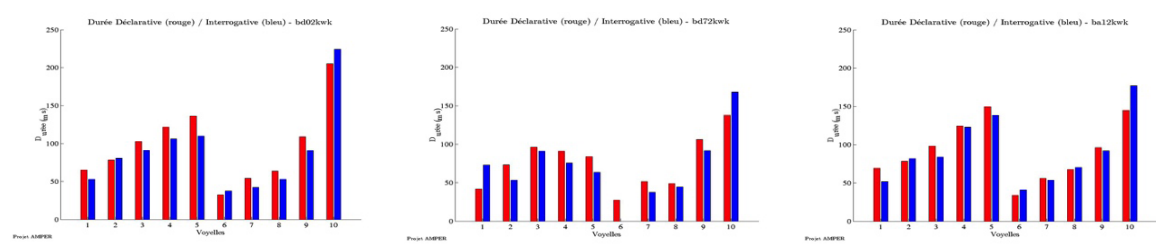

Nas sentenças com núcleo oxítona, o padrão de supressão recai sobre as sílabas átonas internas do enunciado, "gosta do", sílabas 6 e 7, também para a mulher de Fortaleza. A falante do Rio de Janeiro que mantém o seu padrão rítmico de leitura, criando mesmo dois grupos rítmicos simétricos no interior do enunciado, fazendo o contraponto entre "gosta" e "bisavô", sílabas 5 e 10. O mesmo realiza a falante de Fortaleza apesar da supressão silábica em "gosta" e menos a falante de Salvador que apresenta dois grupos rítmicos também de leitura, mas menos regulares ou simétricos que os de Fortaleza e Rio de Janeiro.

Em termos de intensidade, no caso do Rio de Janeiro, a queda abrupta de intensidade se dá mesmo no padrão oxítono, no caso das declarativas (vermelho), estratégia de leitura que se repete no falante masculino, como se verá a seguir. 
Figura 21 - Intensidade de enunciado com núcleo oxítono: mulheres

Enunciado 3: O bisavô gosta do bisavô./ O bisavô gosta do bisavô?

Declarativas (vermelho) e interrogativas (azul).

Intensidade das mulheres de Salvador, Fortaleza, e Rio de Janeiro
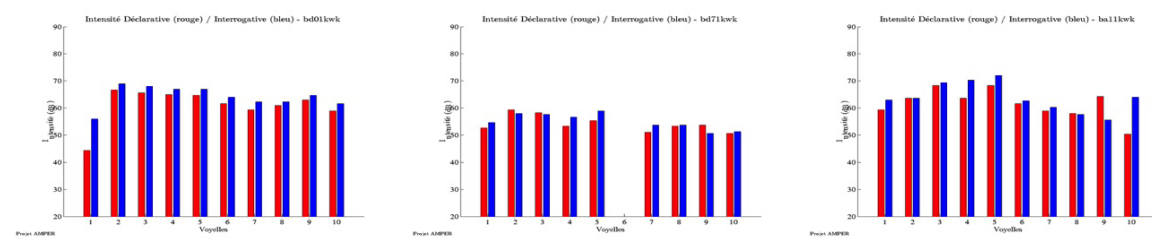

Figura 22 - Intensidade de enunciado com núcleo oxítono: homens

Enunciado 3: O bisavô gosta do bisavô./ O bisavô gosta do bisavô?

Declarativas (vermelho) e interrogativas (azul).

Intensidade dos homens de Salvador, Fortaleza, e Rio de Janeiro
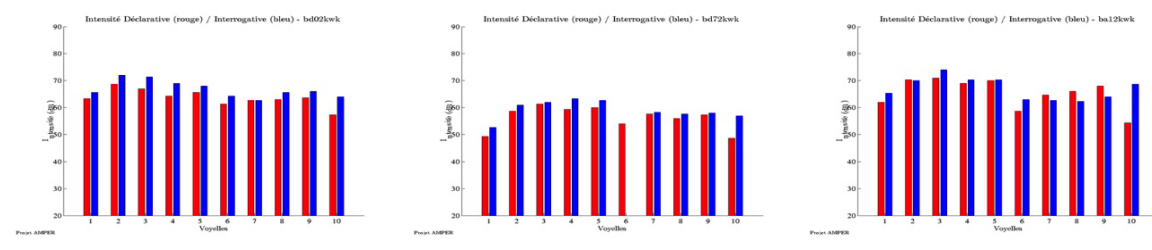

Assim como para as mulheres, no caso do Rio de Janeiro, a queda abrupta de intensidade se dá mesmo no padrão oxítono, nas declarativas (vermelho), estratégia de leitura que associada ao comportamento de duração e de F0 diferencia os falantes do Rio de Janeiro pela aprendizagem de um padrão prosódico de leitura que é aplicado à oralização dos dados, no momento da leitura do corpus.

\section{Considerações finais}

Procuramos estabelecer um diálogo entre os resultados de nossas análises e dados de projetos de pesquisa similares para as três capitais. Em termos de duração, a distribuição regular da duração ao longo do enunciado, formando grupos rítmicos simétricos, aponta para a realização de uma fala planejada, leitura, no caso das três localidades, o que atribuímos ao grau de escolaridade dos falantes, que já adquiriram a prosódia de leitura, aprendida nas práticas escolares. A internalização 
de um padrão mais silábico e regular de leitura dos falantes de Salvador, Fortaleza e do Rio de Janeiro também se destaca no caso das proparoxítonas e das oxítonas.

No caso dos homens, em termos de duração, a distribuição das reduções e alongamentos vocálicos por sílaba também é muito regular, tanto nos dados do Rio de Janeiro quanto nos de Salvador e menos nos de Fortaleza. Os resultados referentes à intensidade não podem ser considerados, sem normalização, em termos brutos, pois as condições de gravação certamente não foram as mesmas, o que afeta o dado em $\mathrm{dB}$. Entretanto, podemos comparar a distribuição dos valores de intensidade ao longo do enunciado, comparando as diferenças e proporções de intensidade interssilábicas, uma vez que são as mesmas frases e que a variação no interior do enunciado da intensidade é desconsiderável.

Assim como para as mulheres, nos dados dos homens, para as três localidades, a intensidade da sílaba tônica no núcleo é mais importante na interrogativa (azul) do que na declarativa (vermelho). A partir dos dados analisados, encontramos diferenças significativas em relação às modalidades - declarativa e interrogativa total - e, em menor medida, em relação à origem dos falantes.

\subsection{Com relação às modalidades podemos afirmar que:}

a. A pretônica que antecede a última tônica é mais alta na modalidade declarativa do que na interrogativa total;

b. A duração da última tônica é menor na modalidade declarativa que na interrogativa total, menos para a variedade Salvador;

c. A intensidade da última tônica é menor na modalidade declarativa que na interrogativa total;

d. O contorno entonativo da modalidade declarativa é descendente, ao passo que o da interrogativa total é, predominantemente, circunflexo proparoxítono e paroxítono.

e. No padrão oxítono das interrogativas, temos resultados ascendentes para o Rio de Janeiro, truncados para Salvador (ascendente com começo de queda) e circunflexo na mulher, mas truncado no homem de Fortaleza. 


\subsection{Com relação à origem dos falantes podemos afirmar que:}

a. Nas declarativas, o comportamento da F0 é descendente da pretônica nuclear, descendendo gradualmente, até a postônica (linha de declinação). Entretanto, nas interrogativas, o movimento de F0 é sempre ascendente na sílaba tônica nuclear, nas três localidades. Fortaleza diverge de Rio de Janeiro e Salvador, pois a subida da F0 na tônica é seguida de movimento descendente na própria tônica.

b. A diferença de duração entre sílabas tônicas e átonas em posição nuclear agrupa Rio de Janeiro e Salvador em oposição ao comportamento de Fortaleza. Em Fortaleza a tônica nuclear é proporcionalmente mais longa do que a postônica que chega inclusive à elisão vocálica na mulher.

c. A queda de intensidade ao longo do enunciado é visível nas três variedades, no entanto, a queda no núcleo da tônica para a postônica é mais abrupta em Fortaleza devido aos apagamentos finais.

d. O contorno entonativo da modalidade declarativa é descendente nas três localidades, ao passo que o da interrogativa total é predominantemente circunflexo nos núcleos paroxítonos e proparoxítonos. Nos núcleos oxítonos é variável. Segundo sugestão de Moraes (2016, informação verbal) seria importante verificar se o padrão ascendente das oxítonas é um caso de truncamento ou um padrão diferente do padrão das paroxítonas através de testes perceptuais com estímulos gerados a partir da manipulação de síntese em pontos chave dos enunciados.

\section{Agradecimentos}

Agradecemos a João Antônio de Moraes e Zulina Souza de Lira por terem disponibilizado os dados de Salvador e Fortaleza para esta análise. E a Albert Rilliard pelas observações e sugestões teórico-metodológicas para a análise e revisão final do texto. Igualmente, o trabalho atento e cuidadoso, a leitura construtiva dos dois revisores. Quaisquer imprecisões ou erros ainda remanescentes são de responsabilidade nossa, inteiramente. 


\section{Referências}

ANTUNES, L. Os projetos AMPER e ALIB e o estudo da variação prosódica no estado de Minas Gerais. In: GSCP INTERNATIONAL CONFERENCE, 2012, Belo Horizonte. Arquivos... Belo Horizonte: UFMG, 2012. Disponível em: <http://150.164.100.248/gscp2012-eng/ data1/arquivos/leandra_antunes.pdf $>$. Acesso em: 17 de janeiro de 2017

ARANTES, P. Time-normalization of Fundamental Frequency Contours: a Hands-On Tutorial. In: MEIRELES, A. (Org.). Courses on Speech Prosody. Newcastle upon Tyne: Cambridge Scholars Publishing, 2015. v. 1, p. 98-123.

BARBOSA, P. A. From syntax to acoustic duration: A dynamical model of speech rhythm production, Speech Communication, v. 49, p. 725-742, 2007. https://doi.org/10.1016/j.specom.2007.04.013.

BLANCHE-BENVENISTE, C. Lo hablado y lo escrito. In: Estudios lingüisticos de la relación entre oralidad y escritura. Tradução de Lía Varela. Barcelona: Gedisa, p. 29-63, 1998.

BOERSMA, P.WEENINK, D. (1992-2014) «PRAAT: doing phonetics by computer». Versão 5.3.84. Disponível em: $<$ www.praat.org $>$. Acesso em: 18 de setembro de 2016.

CINTRA, G. Distribuição de padrões acentuais no vocábulo em português, Confluência, v. 5 n. 3, p. 82-93, 1997.

CONTINI, M.; ROMANO, A.; MOUTINHO, L. DE C.; FERNANDEZ REI, E. L'Avancement des recherches en Géoprosodie et le projet AMPER. Estudios de Fonética Experimental, EFE, Fundación Dialnet, v. XVIII, p. 109-122, 2009. Disponível em: <http://stel.ub.edu/labfon/ sites/default/files/XVIII-11.pdf>. Acesso em: 20 de setembro de 2016.

CUNHA, C. S. Entoação regional no português do Brasil. 2000. Tese (Doutorado em Língua Portuguesa) -Faculdade de Letras da Universidade Federal do Rio de Janeiro, Rio de Janeiro, 2000.

CUNHA, C. S. Atlas linguístico do Brasil: uma análise das questões de prosódia. In: MOTA, J. A; CARDOSO, S. M. (Org.). Documentos 2: Projeto Atlas Linguístico do Brasil. Salvador: Editora Quarteto, 2005. v.1.p.187-205. 
CUNHA, C. S. Corpus ALIB: uma base de dados para pesquisas atuais e futuras. In: CUNHA, C. S. (Org.) Estudos geo-sociolinguísticos. Rio de Janeiro: Programa de Pós Graduação em Letras Vernáculas, UFRJ, 2006. p. 67-81.

GOMES DA SILVA, C. Análise entonacional e pragmática de conversas telefônicas coloquiais: os enunciados interrogativos totais nas variedades de Buenos Aires e Santiago do Chile. 2014. Dissertação (Mestrado em Letras Neolatinas) - Faculdade de Letras da Universidade Federal do Rio de Janeiro, Rio de Janeiro, 2014. Disponível em: < http://www.letras.ufrj. $\mathrm{br} /$ pgneolatinas/media/bancoteses/carolinagomesmestrado.pdf $>$. Acesso em: 20 de março de 2017.

LADD, D. Robert. Intonational Phonology. 2. ed. Cambridge: Cambridge University Press, 2008. https://doi.org/10.1017/CBO9780511808814.

LIRA, Z. de. A entoação modal em cinco falares do Nordeste brasileiro. 2009. Tese (Doutorado em Lingüística) - UFPB, João Pessoa, 2009. Disponível em: <http://bdtd.biblioteca.ufpb.br/tde_busca/arquivo. php? codArquivo=449>. Acesso em: 20 de março de 2017 .

MIRANDA, L. S. Análise da entoação do português do Brasil segundo o modelo IPO. 2015. Dissertação (Mestrado em Língua Portuguesa) Faculdade de Letras da Universidade Federal do Rio de Janeiro, Rio de Janeiro, 2015. Disponível em: < http://www.letras.ufrj.br/posverna/ mestrado/MirandaLS.pdf>. Acesso em: 20 de março de 2017.

MORAES, J. A de; ABRAÇADO, M. J. A. A descrição prosódica do português do Brasil no AMPER, Geolinguistique - Hors série, n. 3, p. 337-345, 2005.

MORAES, J. A. de. The pitch accents in Brazilian Portuguese: analysis by synthesis. Speech Prosody, v. 4, p. 389-397, 2008. Disponível em: $<$ http://sprosig.isle.illinois.edu/sp2008/papers/8inv.pdf>. Acesso em: 15 de dezembro de 2016.

MORAES, J. A. de. Data Analysis. Rio de Janeiro: Curso de Pós Graduação em Letras Vernáculas e Neolatinas da UFRJ, 2016.

MOUTINHO, L.; COIMBRA, R. L.; RILlIARD, A.; ROMANO, A. Mesure de la variation prosodique diatopique en portugais européen. Estudios de fonética experimental, v. 20, p. 33-55, 2011. 
NUNES, V. G. A prosódia de sentenças interrogativas totais nos falares catarineneses e sergipanos. 2015. Tese (Doutorado) - Programa de Pós Graduação em Lingüística da Universidade Federal de Santa Catarina, Florianópolis, 2015.

REIS, C. L'Interaction entre l'Accent, l'Intonation et le Rythme em Portugais brésilien: Étude Acoustique de la Prosodie. 1995. Tese (Doutorado) - Institut de Phonétique, Université de Provence, Aix-enProvence, 1995.

RILLIARD, A.; LAI, J.-P. Outils pour le calcul et la comparaison prosodique dans le cadre du projet AMPER - l'exemple des variétés Occitane et Sarde. In: SYMPOSIUM INTERNATIONAL SUR LA VARIATION DIATOPIQUE DE L'INTONATION DANS LE DOMAINE ROUMAIN ET ROMAN, 2008, Iasi, Roumanie. Actes... Iasi, Roumanie: Editura Universitatii «Alexandru Ioan Cuza», 2008. p. 217-229.

RILLIARD, A. La base de données AMPER. Géolinguistique, hors-série, n. 4, 2011.

RILLIARD, A. Prosodie et Interaction Homme-Machine: Étude de la variation démarcative, diatopique, diachronique \& expressive. 2014. Mémoire (Habilitation à Diriger des Recherches de 1'Université ParisSud) - Université Paris-Sud, Paris, 2014.

ROMANO, A.; CONTINI, M.; LAI, J. P.; RILLIARD, A. Distancias prosódicas entre variedades románicas en el marco del proyecto AMPER. Revista Lingüística Iberoamericana, v. IX, n. 17, p. 13-26, 2011. Disponível em: <http://www.ibero-americana.net/cgibin/search.cgi?n $=$ verlagskatalog\&lang=en\&kat=RILI $>$. Acesso em: 15 de dezembro de 2016.

ROSSI, Mario. Peut-on prédire l'organisation prosodique du langage spontané?. Etudes de linguistique appliquée, v. 66, p. 20-48, 1987.

SEARA, I; REBOLLO-COUTO, L. Entoação de frases declarativas e interrogativas totais no falar fluminense e catarinense. In: CONGRESO INTERNACIONAL DE LA ASOCIACIÓN DE LINGÜÍSTICA Y FILOLOGÍA DE LAAMÉRICA LATINA(ALFAL), XVI., 2011, Alcalá de Henares (Espanha), Actas... Alcalá de Henares: ALFAL, 2011. v. 1, p. 1-7. 
SILVA, J. C. B. Caracterização prosódica dos falares brasileiros: as orações interrogativas totais. 2011. Dissertação (Mestrado em Língua Portuguesa) - Faculdade de Letras da Universidade Federal do Rio de Janeiro, Rio de Janeiro, 2011. Disponível em: <http://www.letras.ufrj. br/posverna/mestrado/SilvaJCB.pdf > . Acesso em: 20 de março de 2017.

SILVESTRE, A. P. S. A entoação regional dos enunciados assertivos nos falares das capitais brasileiras. 2012. Dissertação (Mestrado em Língua Portuguesa) - Faculdade de Letras da Universidade Federal do Rio de Janeiro, Rio de Janeiro, 2012. Disponível em: <http://www.letras.ufrj.br/ posverna/mestrado/SilvestreAPS.pdf>. Acesso em: 20 de março de 2017.

VAISSIÈRE, Jacqueline. Langues, prosodies et syntaxe: Prosodie et syntaxe. TAL. Traitement Automatique des Langues, v. 38, n. 1, p. 53-82, 1997.

XU, Y. Transmitting tone and intonation simultaneously - the parallel encoding and target approximation (PENTA) model. In: INTERNATIONAL SYMPOSIUM ON TONAL ASPECTS OF LANGUAGES: WITH EMPHASIS ON TONE LANGUAGES, 2004, Beijing, 2004. Disponível em: <http://www.phon.ucl.ac.uk/home/yi/ yispapers/Xu_TAL2004.pdf>. Acesso em: 15 de dezembro de 2016. 